\title{
TEORI BELAJAR HUMANISTIK DAN IMPLIKASINYA TERHADAP PEMBELAJARAN PENDIDIKAN AGAMA ISLAM
}

\author{
Budi Agus Sumantri*, Nurul Ahmad** \\ Universitas Islam Negeri Sunan Kalijaga Yogyakarta \\ *budisumantri0045@gmail.com \\ **nurulahmad424@gmail.com
}

\begin{abstract}
This study aims to describe humanistic learning theory and its implications for the learning of Islamic Education. This research method uses library research or library research to be analyzed and concluded. Research data is obtained from recording books and journals. The results of this study contain an understanding of bumanistic learning, bumanistic learning figures listed: 1) Abraham Maslow as follows; a) Abraham Maslow's biography, b) Abraham Maslow's humanistic learning theory c) Implications of Abraham Maslow's Theory in Islamic Education. 2) Carl Rogers's bumanistic learning theory and the implications of Carl Rogers's theory in learning Islamic Education. Conclusion of humanistic theories to bumanize bumans. the learning process is considered successful if the student discusses his environment and claims bimself. Students in the learning process must try to make it more slowly and able to achieve self-actualization as well as possible.
\end{abstract}

Keywords: Learning theory, Humanistic, PAI

\begin{abstract}
Abstrak: Penelitian ini bertujuan untuk mendeskripsikan tentang teori belajar humanistik dan implikasinya terhadap pembelajaran Pendidikan Agama Islam. Metode penelitian ini adalah menggunakan literature research atau penelitian kepustakaan yang akan dianalisis dan disimpulkan. Data penelitian diperoleh dari pencatatan buku dan jurnal. Hasil penelitian ini berupa pengertian teroi belajar humanistik, tokoh belajar humanistik yang meliputi: 1) Abraham Maslow sebagai berikut; a) biografi Abraham Maslow, b) teori belajar humanistik Abraham Maslow c) Implikasi Teori Abraham Maslow dalam Pendidikan Agama Islam. Aliran teori humanistik Rogers dan implikasinya pada pelajaran Pendidikan Agama Islam. Kesimpulan teori humanistik bertujuan memanusiakan manusia semanusiawi mungkin. Proses pembelajaran dinilai efektif bila peserta didik memahami dirinya dan lingkungan sekitarnya. Peserta didik dalam rangkaian pembelajaran hendaknya berupaya agar cepat atau lambat dia dapat mengaktualisasikan dirinya sebaik mungkin.
\end{abstract}

Kata Kunci: Teori belajar, Humanistik, PAI

Fondatia : Jurnal Pendidikan Dasar

Volume 3, Nomor 2, September 2019; 1-18

https://ejournal.stitpn.ac.id/index.php/fondatia 


\section{PENDAHULUAN}

Pendidikan dan pengajaran adalah salah satu upaya mencapai target atau tujuan yang secara runtut mengarah pada perbaikan tingkah laku menuju kedewasaan anak didik. Perubahan-perubahan itu menunjukkan tahap-tahap yang harus dilewati. Tanpa proses itu tujuan tidak dapat tercapai, proses yang dimaksud adalah proses pendidikan dan pengajaran. Pengajaran adalah proses dengan fungsi menuntun peserta didik dalam menjalani kehidupan, yaitu menuntun serta memaksimalkan potensi diri sesuai dengan amanat perkembangan yang harus dilalui para peserta didik. Tugas-tugas perkembangan tersebut meliputi kebutuhan bertahan hidup sebagai individu maupun sebagai makhluk sosial serta sebagai makhluk yang diciptakan Sang Pencipta. ${ }^{1}$

Pendidikan merupakan rangkaian humanisasi berasal dari pemikiran faham humanistik. Hal tersebut relevan dengan arti fundamental faham humanistik sebagai pengedukasian manusia. Sistem edukasi Islam yang disusun di atas fondasi nilai-nilai kemanusiaan sedari awal kelahirannya sejalan dengan esensi Islam sebagai agama yang humanistik. Islam memposisikan aspek kemanusiaan sebagai arah pendidikannya. Edukasi dan proses pembelajaran di bangku sekolah dipandang kurang demokratis. Minimnya wadah bagi siswa atau siswi untuk mengembangkan daya imajinasi dan kreasi dengan sudut pandang mereka. Padahal, daya kreasi dan kompetensi kritis dalam berpikir adalah modal berharga bagi anak supaya dapat mengatasi tantangan dan lebih kompetitif. ${ }^{2}$

Kritik dan rasa prihatin tersebut tentu muncul dengan alasan. Kenyataan proses edukasi di sekolah sejauh ini tidak memberikan kesempatan bagi peserta didik untuk memaksimalkan kreatifitas dan kecakapan berpikir kritis. Peserta didik belum bisa lepas dari anggapan sebagai obyek. Peserta didik dipandang sebagai orang yang tergilas, yang tidak mengerti apapun, orang yang tidak bisa lepas dari belas kasihan, maka dari itu harus disuapi serta dijejali. Anak-anak masih saja menjadi korban indoktrinasi dan pencucian otak. Demi profit tertentu anak-anak terus menerus disuapi kepentingan dan bahan-bahan bagaikan wadah yang tak terisi. Lebih dari satu

\footnotetext{
${ }^{1}$ Sardiman, Interaksi Dan Motivasi Belajar Mengajar, (jakarta: PT Raja Grafindo, 2005), hlm. 25

2 Arbayah, Model Pembelajaran Humanistik, Vol 13. No. 2, Desember 2013, hlm. 204
} 
dekade peserta didik dibenturkan dengan materi hafalan tanpa peluang guna mengembangkan bakat dan kreatifitasnya. ${ }^{3}$

Sehingga untuk mengembangkan kedua daya tersebut, diperlukan sebuah bentuk pendidikan yang efektif, guna tercapainya kedua daya tersebut. Beranjak dari problematika tersebut, anak-anak tidak pantas dianggap sebagai wadah kosong yang berharap diisi dalam rangkaian kegiatan belajar.

\section{PENGERTIAN TEORI BELAJAR HUMANISTIK}

Secara luas definisi teori belajar humanisitk ialah sebagai aktivitas jasmani dan rohani guna memaksimalkan proses perkembangan. Sedangkan secara sempit pembelajaran diartikan sebagai upaya menguasai khazanah ilmu pengetahuan sebagai rangkaian pembentukan kepribadian secara menyeluruh. Pertumbuhan yang bersifat jasmaniyah tidak memberikan perkembangan tingkah laku. Perubahan atau perkembangan hanya disebabkan oleh proses pembelajaran seperti perubahan habit atau kebiasaan, berbagai kemampuan dalam hal pengetahuan, sikap maupun keterampilan. ${ }^{4}$

Dalam pandangan humanism, manusia memegang kendali terhadap kehidupan dan perilaku mereka, serta berhak untuk mengembangkan sikap dan kepribadian mereka. Masih dalam pandangan humanism, belajar bertujuan untuk menjadikan manusia selayaknya manusia, keberhasilan belajar ditandai bila peserta didik mengenali dirinya dan lingkungan sekitarnya dengan baik. Peserta didik dihadapkan pada target untuk mencapai tingkat aktualisasi diri semaksimal mungkin. Teori humanistic berupaya mengerti tingkah laku belajar menurut pandangan peserta didik dan bukan dari pandangan pengamat. ${ }^{5}$

Humanisme meyakini pusat belajar ada pada peserta didik dan pendidik berperan hanya sebagai fasilitator. Sikap serta pengetahuan merupakan syarat untuk mencapai tujuan pengaktualisasian diri dalam lingkungan yang mendukung. Pada dasarnya manusia adalah makhluk yang spesial, mereka mempunyai potensi dan motivasi dalam pengembangan diri maupun perilaku, oleh karenanya setiap individu

\footnotetext{
${ }^{3}$ Ibid., hlm.205

${ }^{4}$ Fajri Ismail, Evaluasi Pendidikan, (Palembang: Tunas Gemilang Press, 2014), hlm. 25

${ }^{5}$ Arbayah, Model Pembelajaran Humanistik.....,hlm. 210
} 
adalah merdeka dalam upaya pengembangan diri serta pengaktualisasiannya. ${ }^{6}$

Penerapan teori humanistic pada kegiatan belajar hendaknya pendidik menuntun peserta didik berpikir induktif, mengutamakan praktik serta menekankan pentingnya partisipasi peserta didik dalam pembelajaran. Hal tersebut dapat diaplikasikan dengan diskusi sehingga peserta didik mampu mengungkapkan pemikiran mereka di hadapan audience. Pendidik mempersilakan peserta didik menanyakan materi pelajaran yang kurang dimengerti. Proses belajar menurut pandangan humanistic bersifat pengembangan kepribadian, kerohanian, perkembangan tingkah laku serta mampu memahami fenomena di masyarakat. Tanda kesuksesan penerapan tersebut yaitu peserta didik merasa nyaman dan bersemangat dalam proses pembelajaran serta adanya perubahan positif cara berpikir, tingkah laku serta pengendalian diri. $^{7}$

\section{TOKOH TEORI BELAJAR HUMANISTIK}

\section{Abraham Maslow}

Bagi penganut teori humanistic, rangkaian pembelajaran berangkat dan kembali kepada individu. Dari teori-teori belajar behavioristik, kognitif dan kunstruktivistik, teori inilah yang paling abstrak, yang mendekati dunia filsafat. Realitasnya pandangan ini membahas pembelajaran dan segala aspeknya dalam kemasan paling ideal. Artinya pandangan ini menaruh minat pada pemikiran pembelajaran yang paling ideal dan relevan dari pada pembelajaran pada umumnya. ${ }^{8}$

a. Biografi Abraham Maslow

Maslow hidup di masa dimana banyak pandangan dan aliran psikologi baru yang hadir sebagai cabang keilmuan. William James mengembangkan aliran Fungsionalisme yang berkembang di Amerika. Di Jerman lahir psikologi gestalt, di wina hadir Sigmund Freud serta aliran behaviorisme John B Watson yang mulai popular di Amerika. Di tahun 1954 Abraham Maslow mempublikasikan

\footnotetext{
${ }^{6}$ Endang Komara, Belajar dan Pembelajaran Interaktif, (Bandung: PT Refrika Aditama, 2014), hlm. 2

${ }^{7}$ Suprihatin, Pendekatan Humanistik Dalam Pengembangan Kurikulum Pendidikan Agama Islam, Vol. 3, No. 1, Januari - Juni 2017, hlm.94

${ }^{8}$ Eveline Siregar dan Hartini Nara, Teori Belajar dan Pembelajaran, (Bogor: Ghalia Indonesia, 2011), hlm. 34
} 
karyanya berupa buku dengan judul Motivation and Personality, dua aliran yang mendapat tempat di perguruan tinggi Amerika ialah Signumd Freud dengan Psikoanalisanya dan John B. Watson dengan Behaviorismenya.

Sedangkan Maslow ialah psikolog yang oleh banyak pihak digelari sebagai bapak psikologi humanistic. Kepopulerannya dapat ditemukan melalui sumbangsihnya dalam ilmu geografi serta demografi. Berkat teori hierarki kebutuhan yang dicetuskannya, namanya menjadi populer. Teori kebutuhan adalah pemikiran kesehatan rohani berdasarkan pemenuhan kebutuhan alami manusia guna pengaktualisasian diri. ${ }^{10}$

Maslow lahir di New York pada 1908, ia dikenal dengan jasanya membidani lahirnya pandangan pengaktualisasian diri. Ia wafat pada 1970 di California, Amerika. Maslow adalah lelaki yang cerdas, semasa kecil ia menjalin hubungan yang kurang baik dengan ibundanya yang keras dan kerap melakukan tingkah laku yang tidak ganjil. Ia menceritakan dirinya di waktu anak-anak sebagai pemalu namun gemar membaca buku. Namun maslow hanya sementara tidak menyukai dirinya pribadi. Ia sadar akan potensi yang dimilikinya, serta menjadi bapak psikologi humanistic populer yang mendorong adanya perubahan social yang positif. ${ }^{11}$

b. Teori belajar humanistik Abraham Maslow

Dalam perspektif humanistik (humanistic perspective) menuntut potensi peserta didik dalam proses tumbuh kembang, kebebasan menemukan jalan hidupnya. ${ }^{12}$ Humanistic menganggap peserta didik sebagai subjek yang merdeka guna menetapkan tujuan hidup dirinya. Peserta didik dituntun agar memiliki sifat tanggung jawab terhadap kehidupannya dan orang di sekitarnya. ${ }^{13}$

Pembelajaran humanistic menaruh perhatian bahwa pembelajaran yang pokok yaitu upaya membangun komunikasi dan hubungan individu dengan

\footnotetext{
${ }^{9}$ Iskandar, Implementasi Teori Hirarki Kebutuhan Abraham Maslow Terhadap Peningkatan Kinerja Pustakawan, Vol. 4 No. 1, Januari - Juni 2016, hlm. 27

${ }^{10}$ Eka Nova Irawan, "Buku Pintar Pemikiran Tokoh-Tokob Psikologi dari Klasik Sampai Modern," (Yogyakarta: IRCiSoD, 2005), 235.

${ }^{11}$ Howard S. Freidman dan Moiriam W. Schustackk, Keperibadian Teori Klasik dan Riset Modern, (Jakarta: Erlangga, 2008), hlm. 350-351

12 Jhon W. Santrock, Psikologi Pendidikan, (Jakarta: Salemba Humanika, 2009), hlm. 201.

${ }_{13}$ Arbayah, Model Pembelajaran Humanistik......,hlm.215
} 
individu maupun individu dengan kelompok. Edukasi bukan semata-mata memindah khazanah pengetahuan, menempa kecakapan berbahasa para peserta didik, tapi sebagai wujud pertolongan supaya siswa mampu mengaktualisasikan dirinya relevan dengan tujuan pendidikan. Edukasi yang berhasil pada intinya adalah kecakapan menghadirkan makna antara pendidik dengan pembelajar sehingga dapat mencapai tujuan menjadi manusia yang unggul dan bijaksana. Maksudnya ialah menuntun peserta didik bahwa mereka butuh pendidikan karakter. Pendidik memfasilitasi siswa menggali, mengembangkan dan menerapkan kecakapan-kecakapan yang mereka punya supaya mampu memaksimalkan potensinya. ${ }^{14}$

Maslow terkenal sebagai bapak aliran psikologi humanistic, ia yakin bahwa manusia berperilaku guna mengenal dan mengapresiasi dirinya sebaikbaiknya. Teori yang termasyhur hingga saat ini yaitu teori hirarki kebutuhan. Menurutnya manusia terdorong guna mencukupi kebutuhannya. Kebutuhankebutuhan itu mempunyai level, dari yang paling dasar hingga level tertinggi. Dalam teori psikologinya yaitu semakin besar kebutuhan maka pencapaian yang dipunyai oleh individu semakin sungguh-sungguh menggeluti sesuatu. ${ }^{15}$

Perspektif ini diasosiasikan secara dekat dengan keyakinan Abraham Maslow $(1954,1971)$ bahwa kebutuhan dasar tertentu harus dipenuhi sebelum kebutuhan yang lebih tinggi dapat dipuaskan. Menurut hierarki kebutuhan Maslow, pemuasan kebutuhan seseorang dimulai dari yang terendah yaitu: 1) fisiologis, 2) rasa aman, 3) cinta dan rasa memiliki, 4) harga diri, 5) aktualisasi diri. $^{16}$

\footnotetext{
14 Ibid., hlm.215-216

${ }^{15}$ Endang Komara, Belajar dan Pembelajaran.....,hlm. 3

${ }^{16}$ Jhon W. Santrock, Psikologi Pendidikan....,hlm. 201
} 


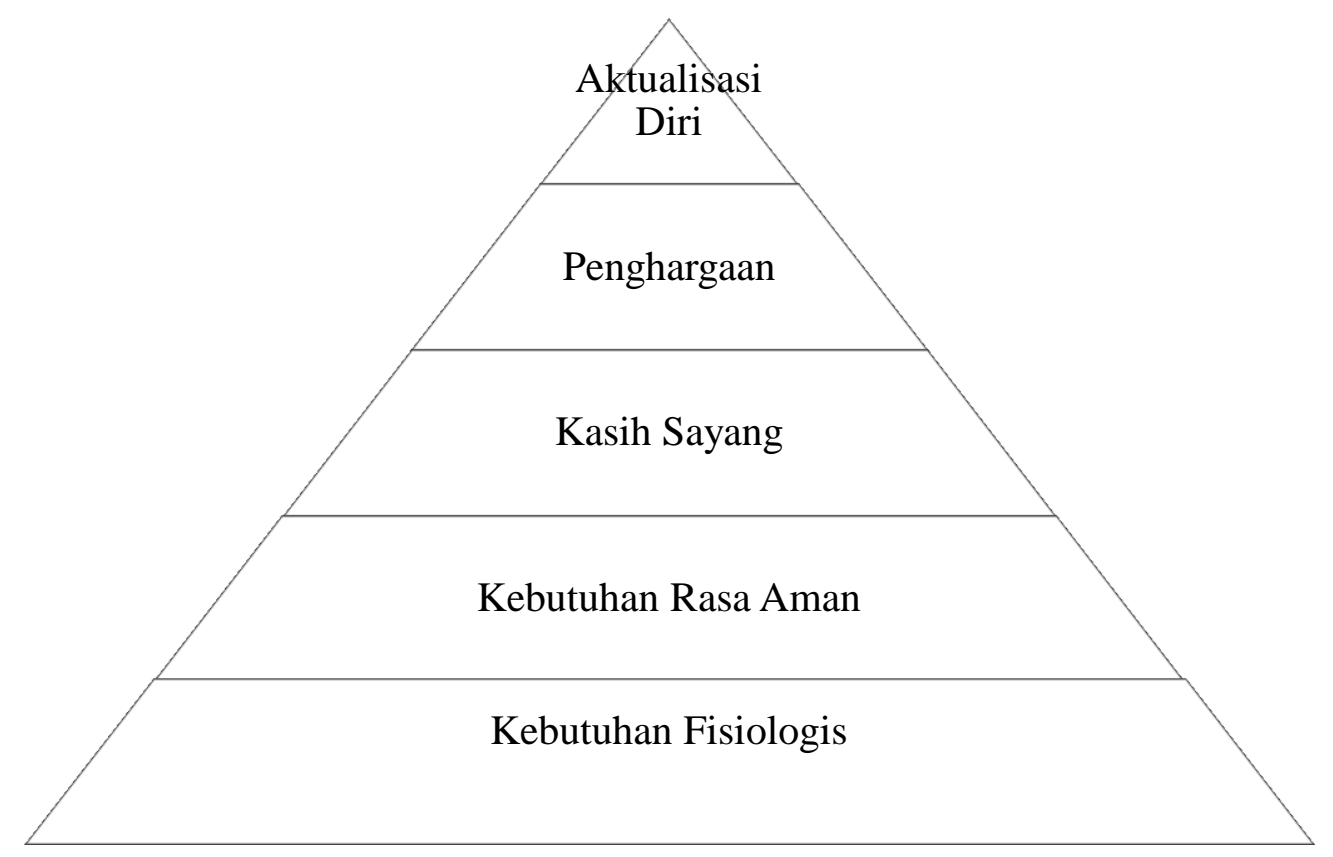

1) Kebutuhan Fisiologis (Physiological Needs)

Kebutuhan fisiologis terdiri dari kebutuhan pokok, yang bersifat mendasar. Kadang kala disebut kebutuhan biologis di tempat kerja serta kebutuhan untuk menerima gaji, cuti, dana pensiunan, masa-masa libur, tempat kerja yang nyaman, pencahayaan yang cukup suhu ruangan yang baik. Kebutuhan tersebut biasanya paling kuat dan memaksa sehingga harus dicukupi terlebih dahulu untuk beraktifitas sehari-hari. Ini menandakan bahwasanya dalam pribadi seseorang yang merasa serba kekurangan dalam kesehariannya, besar kemungkinan bahwa dorongan terkuat adalah kebutuhan fisiologis. Dalam artian, manusia yang katakanlah melarat, bisa jadi selalu terdorong akan kebutuhan tersebut. $^{17}$

\section{2) Kebutuhan Akan Rasa Aman (Safety Needs)}

Sesudah kebutuhan fisiologis tercukupi, maka timbul kebutuhan akan rasa aman. Manusia yang beranggapan tidak berada dalam keamanan membutuhkan keseimbangan dan aturan yang baik serta berupaya menjauhi hal-hal yang tidak dikenal dan tidak diinginkan. Kebutuhan rasa aman menggambarkan kemauan mendapatkan keamanan akan upah-upah yang ia peroleh dan guna menjauhkan dirinya dari ancaman, kecelakaan, kebangkrutan, sakit serta marabahaya. Pada

${ }^{17}$ Iskandar, Implementasi Teori Hirarki....., hlm. 27 
pengorganisasian kebutuhan semacam ini Nampak pada minat akan profesi dan kepastian profesi, budaya senioritas, persatuan pekerja atau karyawan, keamanan lingkungan kerja, bonus upah, dana pensiun, investasi dan sebagainya. ${ }^{18}$

3) Kebutuhan Untuk Diterima (Social Needs)

Sesudah kebutuhan fisiologikal dan rasa aman tercukupi, maka fokus individu mengarah pada kemauan akan mempunyai teman, rasa cinta dan rasa diterima. Sebagai makhluk social, seseorang bahagia bila mereka disukai serta berupaya mencukupi kebutuhan bersosialisasi saat di lingkungan kerja, dengan cara meringankan beban kelompok formal atau kelompok non formal, dan mereka bergotong royong bersama teman setu tim mereka di tempat kerja serta mereka berpartisipasi dalam aktifitas yang dilaksanakan oleh perusahaan dimana mereka bekerja.

4) Kebutuhan Untuk Dihargai (SelfEsteem Needs)

Pada tingkat selanjutnya dalam teori hierarki kebutuhan, Nampak kebutuhan untuk dihargai, disebut juga kebutuhan "ego". Kebutuhan tersebut berkaitan dengan keinginan guna mempunyai kesan positif serta mendapat rasa diperhatikan, diakui serta penghargaan dari sesama manusia. Pada pengorganisasian kebutuhan akan penghargaan memperlihatkan dorongan akan pengakuan, responsibilitas tinggi, status tinggi dan rasa akan diakui atas sumbangsih terhadap kelompok.

5) Kebutuhan Aktualisasi-Diri (Self Actualization)

Kebutuhan kebutuhan tersebut merupakan kebutuhan akan pemenuhan diri pribadi, termasuk level kebutuhan teratas. Kebutuhan tersebut diantaranya yaitu kebutuhan akan perkembangan bakat dan potensi yang ada pada diri sendiri, memaksimalkan kecakapan diri serta menjadi insan yang unggul. Kebutuhan akan pengaktualisasian diri pribadi oleh kelompok mampu dicukupi dengan memberikan peluang untuk berkembang, tumbuh, berkreasi serta memperoleh pelatihan guna memperoleh tugas yang sesuai dan mendapat keberhasilan. ${ }^{19}$

Menurut Abraham Maslow "Self-actualization, namely, to the tendency for bim to become actualized. This tendency might be hrase as the desire to become more and more what

\footnotetext{
${ }^{18}$ Ibid., hlm. 27

${ }^{19}$ Ibid., hlm. 28
} 
one idiosyncratically is, to become everything that one is capable of becoming. ${ }^{20}$ Artinya bahwa kebutuhan aktualisasi diri adalah kecenderungan seseorang untuk mengerahkan semua kemampuan atau keinginannya secara terus menerus dalam menjadi pribadi yang lebih baik.

Meskipun seseorang individu telah memenuhi kebutuhan-kebutuhan diatas, baik kebutuhan fisiologis, kebutuhan rasa aman, kebutuhan akan percintaan dan rasa mempunyai, meliputi kebutuhan akan rasa penghargaan, ia masih akan diliputi oleh emosi yang tidak puas. Ketidak puasan ini berasal dari dorongan dirinya yang terdalam, karena merasa ada kualitas atau potensi dirinya yang belum teraktualisasikan. Pada intinya seseorang individu akan dituntut untuk jujur terhadap semua potensi dan sifat yang ada pada dirinya. ${ }^{21}$

c. Implikasi Teori Abraham Maslow dalam Pendidikan Agama Islam

Maslow merupakan salah satu pelopor aliran psikologi humanistic Maslow percaya bahwa manusia terdorong untuk menerima dan memahami dirinya sebisa mungkin. teori Hierarchy of Needs (Hirarki Kebutuhan) merupakan teorinya yang terkenal sampai saat ini. Menurut Maslow, manusia terdorong oleh pemenuhan kebutuhan-kebutuhan hidupnya.

Kebutuhan-kebutuhan tersebut mempunyai tahapan atau tingkatan, mulai dari yang rendah sampai yang paling tinggi self actualization (aktualisasi diri). hirarki kebutuhan (Hierarchy of needs) dari Maslow mengungkapkan bahwa manusia memiliki 5 kebutuhan yaitu kebutuhan fisiologis (physiological needs), kebutuhan rasa aman (safety and security needs), kebutuhan kasih sayang dan memiliki (love and belonging needs), kebutuhan harga diri (esteem needs), dan kebutuhan aktualisasi diri (self-actualization). Sehingga pendidikan humanistik haruslah pendidikan yang mencakup 5 kebutuhan tersebut. ${ }^{22}$

Kebutuhan-kebutuhan tersebut mempunyai tahapan atau tingkatan, mulai dari yang rendah sampai yang paling tinggi self actualization (aktualisasi diri). hirarki kebutuhan (Hierarchy of needs) dari Maslow mengungkapkan bahwa manusia memiliki 5 kebutuhan yaitu kebutuhan fisiologis (physiological needs), kebutuhan

\footnotetext{
${ }^{20}$ Abraham H.Maslow, Motivation And Personality, (Harper \& Row: 1970), hlm. 46

${ }^{21}$ Hasyim Muhammad, Dialog Antara Tasawnf...., hal. 78-79

22 Arbayah, Model Pembelajaran Humanistik......,hlm.206-207
} 
rasa aman (safety and security needs), kebutuhan kasih sayang dan memiliki (love and belonging needs), kebutuhan harga diri (esteem needs), dan kebutuhan aktualisasi diri (self-actualization). Sehingga pendidikan humanistik haruslah pendidikan yang mencakup 5 kebutuhan tersebut. ${ }^{23}$ Aktualisasi diri (self-actualization), kebutuhan Maslow yang tertinggi dan paling sulit dicapai dan paling sulit dicapai adalah motivasi untuk mengembangkan sepenuhnya potensi seseorang sebagai manusia. Dalam pandangan maslow aktualisasi akan terjadi setelah kebutuhan yang rendah telah terpenuhi. Maslow memperingatkan bahwa sebagian besar orang berhenti mematangkan diri yang tinggi dan mereka tidak pernah mengaktualisasikan dirinya.

Dalam konteks pembelajaran, kehadiran teori Maslow tentang motivasi dapat menjadi satu rujukan ilmiah dalam membangun motivasi sumber daya Manusia (SDM) dalam dunia pendidikan. Motivasi dalam pembelajaran akan mendorong siswa agar mengembangkan potensinya secara maksimal. Sehingga untuk membangun motivasi dalam konteks ini membutuhkan kerangka teori yang membahas kebutuhan manusia secara menyeluruh

Adapun implikasi positif teori ini ke dalam pembelajaran PAI adalah sebagai berikut.

1. Memenuhi kebutuhan fisiologis ialah kebutuhan makan dan minum, pakaian, tempat tinggal, termasuk kebutuhan biologis. yang merupakan kebutuhan paling dasar karena dibutuhkan semua makhluk hidup. ${ }^{24}$ Pemenuhan kebutuhan dasar peserta didik harus di utamakan karena kebutuhan ini sangat mendesak dan hendaknya guru memberikan kesempatan atau bantuan kepada siswa untuk memenuhinya. Dalam pembelajaran PAI sebelum memutuskan cara pembelajaran apa yang pantas diterapkan pada pembelajaran PAI, hendaknya para pendidik mengetahui terlebih dahulu keterlibatan kebutuhankebutuhan yang menjadi dasar motivasi dalam mencapai tujuan pembelajaran PAI Mengakomondasi kebutuhan rasa aman secara fisik maupun psikis.

2. Mengakomondasi kebutuhan rasa aman secara fisik maupun psikis. Aman secara fisik, seperti terhindar dari kriminalisasi, teror, binatang buas, orang

\footnotetext{
${ }^{23}$ Jhon W. Santrock, Psikologi Pendidikan....,hlm. 202

${ }^{24}$ Eveline Siregar dan Hartini Nara, Teori Belajar....,hlm. 38
} 
lain, tempat yang kurang aman dan sebagainya. sedangkan Aman secara psikis, seperti tidak di marah, tidak dibuly, tidak direndahkan, tidak dipindahkan tanpa keterangan, diturunkan pangkatnya dan sebagainya. Kebutuhan akan keamanan di kelas menjadi tanggung jawab guru. Tugas guru ialah menetapkan peraturan dan jaminan atas keselamatan siswa serta kenyamanan kelas.

3. Kebutuhan sosial dibutuhkan seseorang supaya ia dianggap sebagai warga komunitas sosialnya. Bagi seorang siswa agar bisa belajar dengan baik, ia harus merasa diterima dengan baik oleh teman-temannya. Terkait dengan kebutuhan sosial siswa, guru hendaknya memberikan perhatian supaya siswa mampu berinteraksi dengan baik dan mempunyai rasa saling memiliki terhadap teman-temannya serta lingkungan sekelilingnya.

4. Kebutuhan ego termasuk juga keinginan untuk mendapatkan prestasi dan memiliki wibawa. Seseorang membutuhkan sebuah kepercayaan serta tanggung jawab dari orang lain. Dalam pembelajaran, dengan memberikan tugas-tugas yang menantang maka siswa akan terpenuhi egonya._ Prestasi siswa sekecil apapun perlu diberikan apresiasi. Memberikan sebuah penghargaan pada peserta didik mampu memotivasi siswa untuk meningkatkan prestasinya..

5. Kebutuhan aktualisasi merupakan kebutuhan untuk menunjukkan dan membuktikan dirinya pada orang lain. Pada tahapan ini seseorang akan mengembangkan semaksimal mungkin potensi yang mereka miliki. Untuk mengaktualisasikan dirinya peserta didik perlu suasana dan lingkungan yang kondusif._ Ketika peserta didik sudah di tahap aktualisasi diri,guru hanya tinggal memberikan fasilitas yang diperlukan untuk mengembangkan dirinya secara lebih jauh. Abraham Maslow dengan teori motivasinya mengorieantasikan manusia sebagai subjek yang dapat mengembangkan potensi-potensi yang dimilikinya untuk kemudian dapat mengaktualisasikan diri sebagai manusia yang utuh. Konsep ini sejalan dengan tujuan ajaran Agama Islam yang selalu mengedepankan nilai-nilai agama sebagai landasan motivasi untuk berbuat. Salah satunya menjalankan kewajiban khilafah di muka bumi. 


\section{Teori Belajar Humanistik Carl Rogers}

Carl Rogers Carl Ransom Rogers dilahirkan pada tahun 1902 di Oak Park, Illinois, dan wafat pada tahun 1987 di Lajolla, California. Pada masa mudanya, Rogers tidak mempunyai banyak teman sehingga dia lebih banyak menghabiskan waktu-waktunya untuk membaca. Dia akan membaca buku apa saja yang ia ditemui termasuk kamus dan ensiklopedia, meskipun ia sebenarnya sangat menyukai buku-buku petualangan. Ia pernah belajar di bidang agricultural dans sejarah di University of Winconsin. Pada tahun 1928 rogers mendapatkan gelar Master di bidang psikologi dari Universitas Columbia dan kemudian ia mendapatkan gelar Ph.D, di bidang psikologi klinis pada Society for the prevention of Cruelty to Children (bagian studi tentang anak pada perhimpunan pencegahan kekerasan terhadap anak) di Rochester, NY. ${ }^{25}$

Salah satu ranah ketika ide Rogers masih terus memiliki banyak pengaruh adalah dalam peraihan tujuan. Menetapkan dan meraih tujuan adalah suatu cara manusia untuk mengatur kehidupannya supaya dapat memberikan hasil yang diinginkan dan menambah arti pada kegiatan sehari-hari. Menetapkan tujuan merupakan hal yang mudah, namun menetapkan tujuan yang tepat dapat menjadi lebih sulit daripada kelihatannya. ${ }^{26}$

Menurut Rogers, penyebab dari kecemasan psikologis adalah inkongruensi, atau saat diri ideal seseorang tidak cukup bertumpukan dengan konsep dirinya, dan inkongruensi, atau pada saat diri ideal seorang individu tidak cukup untuk berpijak terhadap konsep dirinya, dan inkongruensi ini dapat dipresentasikan melalui tujuan-tujuan yang seseorang pilih untuk diraihnya. Sebagai contoh meraih tujuan untuk berhasil dalam bidang biologi, tetapi bahkan tidak menyukai biologi ataupun membutuhkan keberhasilan tersebut untuk mencapai tujuannya menjadi seorang arsitek. Terdapat kemungkinan bahwa orang tua dari orang tersebut adalah ahli biologi dan selama ini ia diharapkan akan melakukan hal yang sama walaupun merasa bahwa arsitektur lebih menyenangkan dan memuaskan.

\footnotetext{
${ }^{25}$ Endang Komara, Belajar dan Pembelajaran Interaktif, (Bandung: Refika Aditama, 2014), hal. 3.

${ }^{26}$ Jess Feist, Teori Kepribadian, (Jakarta: Penerbit Salemba Humanika, 2009), hal. 33.
} 
Dalam contoh ini, biologi adalah bagian konsep dari diri seseorang, tetapi arsitektur adalah bagian dari diri ideal dari orang tersebut. Inkongruensi antara keduanya dapat menyebabkan stress. Untungnya, Rogers meluaskan ide-ide ini untuk mengajukan bahwa kita semua memiliki proses penilaian organismic (Oraganismic Valuing Process), yaitu insting alami yang menggerakkan kita menuju pencapaian-pencapaian yang sangat bermakna. Dalam contoh di atas, OVP direpresentasikan sebagai insting yang tidak dapat dijelaskan bahwa arsitektur, dan bukan biologi, adalah jalur yang tepat. ${ }^{27}$

Menurut Rogers dalam Jamil Suprihatiningrum, ada dua tipe belajar, yaitu kognitif (kebermaknaan) dan eksperimental (pengalaman). Guru memberikan makna (kognitif) bahwa tidak membuang sampah sembarangan dapat mencegah terjadinya banjir. Jadi, guru perlu menghubungkan pengetahuam akademik ke dalam pengetahuan bermakna. Sementara experimental learning melibatkan peserta didik secara personal, berinisiatif, termasuk penilaian terhadap diri sendiri (self assessment.$^{28}$

Sedangkan menurut Carl Rogers dalam teori belajar bebasnya, menyatakan bahwa tidak ada paksaan atau tekanan dalam belajar. Guru tidak bembuat rencana dalam pembelajaran untuk peserta didik, tidak memberikan kritik atau ceramah kecuali apabila siswa menghendakinya, tidak menilai atau mengkritik pekerjaan murid kecuali apabila siswa memintanya.. ${ }^{29}$

Dalam bukunya "Freedom to Learn", ia memperkenalkan beberapa prinsip-prinsip belajar humanistik yang sangat penting, di antaranya ialah: 1) Manusia itu memiliki kemampuan untuk belajar secara alami. 2) Belajar yang bermakna terjadi apabila subjek matter dirasakan peserta didik mempunyai relevansi dengan maksud-maksudya sendiri. 3) Belajar yang melibatkan suatu perubahan yang ad di dalam tanggapan mengenai dirinya, dianggap mengancam dan cenderung akan ditolaknya. 4) pekerjaan-pekerjaan belajar yang dapat mengancam diri adalah sangat mudah untuk dirasakan dan mudah diasimilasikan

${ }^{27}$ Jess Feist, Teori Kepribadian, (Jakarta: Penerbit Salemba Humanika, 2009), hal. 34.

${ }^{28}$ Jamil Suprihatiningrum, Strategi Pembelajaran: Teori dan Aplikasi, (Yogyakarta: Ar-Media, 2013), hal. 31-32.

${ }^{29}$ Uci Sanusi, Pembelajaran dengan Pendekatan Humanistik, vol.11 No.2 2013, hlm. 126 
apabila ancaman dari luar tersebut semakin kecil. 5) Apabila ancaman kepada diri peserta didik rendah, pengalaman bisa diperoleh dengan melakukan berbagai cara yang bermacam-macam dan terjadilah sebuah proses belajar. 6) Belajar yang berarti bisa di dapatkan peserta didik dengan melakukannya. 7) Belajar dapat diperlancar bilamana peserta didik dilibatkan langsung dalam proses pembelajaran dan ikut serta bertanggung jawab dalam proses belajar tersebut. 8) Belajar atas inisiatif diri sendiri yang melibatkan diri peserta didik seutuhnya, baik itu perasaan maupun segi kognitif, merupakan cara yang bisa memberikan hasil yang mendalam dan lestari. 9) Kepercayaan pada diri sendiri, kemerdekaan, kreatifitas akan lebih mudah untuk dicapai apabila peserta didik dibiasakan untuk mawas diri dan mengeritik dirinya sendiri dan penilaian diri orang lain adalah cara kedua yang juga penting. 10) Belajar yang sangat berperan secara sosial di dunia modern ini adalah belajar yang menyangkut proses belajar, yang terbuka dan terus menerus pada pengalaman dan penyatuannya ke dalam dirinya sendiri mengenai proses perubahan itu. ${ }^{30}$

Carl Rogers menyatakan bahwa peserta didik yang belajar hendaknya tidak ditekan, melainkan dibiarkan belajar bebas, peserta didik diharapkan bisa mengambil sebuah langkah sendiri dan berani bertanggung jawab atas langkahlangkah yang diambilnya sendiri. Dalam konteks tersebut, Rogers menyatakan ada lima hal yang penting dalam proses belajar humanistic, yaitu sebagai berikut. .

1. Hasrat untuk belajar: keinginan untuk belajar dikarenakan adanya dorongan rasa ingin tahu manusia yang terus menerus terhadap dunia sekelilingnya. Dalam proses memecahkan jawabannya, seorang individu mengalami kegiatan-kegiatan belajar.

2. Belajar bermakna: seseorang yang beraktivitas akan selalu mempertimbangkan apakah aktivitas tersebut mempunyai makna bagi dirinya. Jika tidak, tentu tidak akan dilakukannya.

3. Belajar tanpa hukuman merupakan belajar yang terlepas dari hukuman atau ancaman menghasilkan anak bebas untuk melakukan apa saja, dan mengadakan percobaan hingga menemukan sendiri suatu hal yang baru.

${ }^{30}$ Wasty Soemanto, Psikologi Pendidikan, (Jakarta: Bina Aksara, 1987), hal. 129. 
4. Belajar dengan daya usaha atau inisiatif sendiri: menunjukkan tingginya motivasi internal yang dimiliki. Siswa yang banyak inisiatif, akan mampu untuk memandu dirinya sendiri, menentukan pilihannya sendiri dan berusaha mempertimbangkan sendiri hal yang baik bagi dirinya.

5. Belajar dan perubahan: keadaan dunia terus berubah, karena itu peserta didik harus belajar untuk dapat menghadapi serta menyesuaikan kondisi dan situasi yang terus berubah. Dengan begitu belajar yang hanya mengingat fenomena atau menghafal kejadian dianggap tak cukup. ${ }^{31}$

a. Implikasi Teori Belajar Humanistik Carl Rogers dalam Pembelajaran PAI

Implikasi Teori Belajar Humanistik Carl Rogers dalam Pembelajaran PAI

Segi implikasi ini meliputi penerapan teori belajar humanistic dalam proses pembelajaran. Para ahli psikologi humanistic berupaya menggambarkan keterampilan dan informasi kognitif dengan segi-segi afektif, nilai-nilai, dan perilaku antar pribadi. Sehubungan dengan hal tersebut, maka menurut Rogers dalam Sri Rumini dkk, membagi dua macam program, yaitu:_. ${ }^{32}$

\section{Confluent Education}

Confluent education adalah proses pendidikan yang memadukan antara pengalaman afektif dan belajar kognitif (pengetahuan) di dalam kelas. Hal ini adalah cara yang sangat bagus untuk melibatkan peserta didik secara pribadi dalam bahan pelajaran. Dalam pembelajaran ini siswa tidak hanya memperhatikan atau membaca, tetapi siswa juga dapat merasakan, menuliskan, menghayati, berdebat yang positif, dan menyampaikan pendapat mereka.

\section{Cooperative Learning}

Pembelajaran cooperative learning mengacu pada metode pembelajaran, yang mana peserta didik bekerja sama dengan kelompok kecil dan saling membantu dalam belajar. Menurut pernyataan Salvin, anggota-anggota kelompok bertanggung jawab atas ketuntasan tugas-tugas kelompok dan mempelajari materi sendiri. ${ }^{33}$

\footnotetext{
${ }^{31}$ Eveline Siregar, Teori Belajar dan Pembelajaran, (Bogor: Penerbit Ghalia Indonesia, 2011), hal.
} 37.

32 Sri Rumini, Psikologi Pendidikan, (Yogyakarta: UPP IKIP Yogyakarta, 1993), hal. 110-116.

33 Jamil Suprihatiningrum, Strategi Pembelajaran: Teori dan Aplikasi, (Yogyakarta: Ar-Media, 2013), hal. 191 
Menurut Johnson \& Johnson, yang dikutip Jamil Suprihatiningrum, ada lima unsur penting dlaam belajar kooperatif, yakni sebagai berikut: ${ }^{34}$

1. Saling ketergantungan secara positif

Dalam belajar kooperatif peserta didik akan merasa bahwa mereka sedang bekerja bersama untuk mencapai satu tujuan dan terkait satu sama lain. Seorang peserta didik akan sukses apabila bagian kelompoknya juga sukses. peserta didik akan merasa bahwa dia juga bagian dari pada kelompok yang memiliki andil terhadap kesuksesan kelompoknya.

2. Interaksi tatap muka semakin meningkat

Interaksi langsung akan semakin meningkat, Belajar kooperatif akan meningkatkan interaksi peserta didik. Hal ini terjadi jika seorang peserta didik akan membantu temannya yang lain untuk sukses sebagai anggota kelompok. Saling memberikan bantuan akan berlangsung secara alamiah karena kegagalan seseorang dalam kelompok dapat memperngaruhi keberhasilan kelompok. Untuk mengatasi permasalahan ini, peserta didik yang membutuhkan bantuan akan diperoleh dari teman kelompoknya. Interaksi yang terjadi dalam pembelajaran kooperatif ialah dalam tukarmenukar ide berkenaan permasalahan yang sedang dipelajari.

3. Tanggung jawab individual

Tanggung jawab individual di dalam belajar kelompok bisa berupa tanggung jawab peserta didik dalam hal: Pertama membantu temannya yang sedang membutuhkan bantuan, kedua peserta didik tidak bisa hanya sekedar "menebeng" pada hasil kerja teman satu kelompoknya.

4. Keterampilan interpersonal dan kelompok kecil

Keterampilan interpersonal dan kelompok kecil di dalam belajar kooperatif, selain diminta untuk belajar materi yang akan diberikan, peserta didik juga diminta untuk belajar bagaimana agar peserta didik mampu berinteraksi dengan peserta didik lain dalam kelompoknya. Bagaimana peserta didik bersikap selaku anggota kelompok dan menyampaikan gagasan mereka dalam kelompok akan menuntut keterampilan khusus.

${ }^{34}$ Ibid., hal. 194-196. 
5. Proses kelompok

Proses kelompok Belajar kooperatif tidak dapat berlangsung tanpa adanya proses kelompok. Proses kelompok terjadi apabila anggota kelompok mendiskusikan dan bekerja sama bagaimana mereka akan menggapai tujuan dengan baik dan membuat hubungan kerja kelompok yang baik.

\section{KESIMPULAN}

Dalam pandangan humanism, belajar bertujuan untuk menjadikan manusia selayaknya manusia, keberhasilan belajar ditandai bila peserta didik mengenali dirinya dan lingkungan sekitarnya dengan baik. Peserta didik dihadapkan pada target untuk mencapai tingkat aktualisasi diri semaksimal mungkin. Teori humanistic berupaya mengerti tingkah laku belajar menurut pandangan peserta didik dan bukan dari pandangan pengamat. Penerapan teori humanistic pada kegiatan belajar hendaknya pendidik menuntun peserta didik berpikir induktif, mengutamakan praktik serta menekankan pentingnya partisipasi peserta didik dalam pembelajaran. Hal tersebut dapat diaplikasikan dengan diskusi sehingga peserta didik mampu mengungkapkan pemikiran mereka di hadapan audience.

Maslow terkenal sebagai bapak aliran psikologi humanistic, ia yakin bahwa manusia berperilaku guna mengenal dan mengapresiasi dirinya sebaik-baiknya. Teori yang termasyhur hingga saat ini yaitu teori hierarki kebutuhan. Menurutnya manusia terdorong guna mencukupi kebutuhannya. Kebutuhan-kebutuhan itu mempunyai level, dari yang paling dasar hingga level tertinggi. Dalam teori psikologinya yaitu semakin besar kebutuhan maka pencapaian yang dipunyai oleh individu semakin sungguh-sungguh menggeluti sesuatu.

Menurut Rogers dalam Jamil Suprihatiningrum, ada dua tipe belajar, yaitu kognitif (kebermaknaan) dan eksperimental (pengalaman). Guru memberikan makna (kognitif) bahwa tidak membuang sampah sembarangan dapat mencegah terjadinya banjir. Jadi, guru perlu menghubungkan pengetahuan akademik ke dalam pengetahuan bermakna. Sementara experimental learning melibatkan peserta didik secara personal, berinisiatif, termasuk penilaian terhadap diri sendiri (self assessment). 


\section{DAFTAR PUSTAKA}

Arbayah, Model Pembelajaran Humanistik, Vol 13. No. 2, Desember 2013.

Armaja Prawira, Purwa, Psikologi Pendidikan dalam Perspektif Baru, Yogyakarta: Ar-Ruzz Media, 2013.

Feist, Jess, Teori Kepribadian, Jakarta: Penerbit Salemba Humanika, 2009.

Iskandar, Implementasi Teori Hirarki Kebutuban Abraham Maslow Terbadap Peningkatan Kinerja Pustakawan, Vol. 4 No. 1, Januari - Juni 2016.

Ismail, Fajri, Evaluasi Pendidikan, Palembang: Tunas Gemilang Press, 2014

Komara, Endang, Belajar dan Pembelajaran Interaktif, Bandung: PT Refrika Aditama, 2014.

Maslow, Abraham H, Motivation And Personality, Harper \& Row: 1970.

Nova Irawan, Eka, "Buku Pintar Pemikiran Tokoh-Tokoh Psikologi dari Klasik Sampai Modern,” Yogyakarta: IRCiSoD, 2005.

Rumini, Jamil, Psikologi Pendidikan, Yogyakarta: UPP IKIP Yogyakarta, 1993.

S. Freidman, Howard, Keperibadian Teori Klasik dan Riset Modern, Jakarta: Erlangga, 2008.

Sanusi, Uci, Pembelajaran dengan Pendekatan Humanistik, vol.11 No.2, 2013.

Sardiman, Interaksi Dan Motivasi Belajar Mengajar, jakarta: PT Raja Grafindo, 2005.

Siregar, Eveline, Teori Belajar dan Pembelajaran, Bogor: Ghalia Indonesia, 2011.

Soemanto, Wasty, Psikologi Pendidikan, Jakarta: Bina Aksara, 1987.

Suprihatin, Pendekatan Humanistik Dalam Pengembangan Kurikulum Pendidikan Agama Islam, Vol. 3, No. 1, Januari - Juni 2017.

Suprihatiningrum, Jamil, Strategi Pembelajaran: Teori dan Aplikasi, Yogyakarta: ArMedia, 2013.

W. Santrock, John, Psikologi Pendidikan, Jakarta: Salemba Humanika, 2009.

Zulfikar, Konseling Humanistik: Sebuah Tinjauan Filosofi, Vol. 3 No. 1 Januari-Juni 2017. 